\title{
ZNACZENIE ZBIORÓW KOŚCIELNYCH I SZTUKI SAKRALNEJ W UTRWALANIU DZIEDZICTWA RELIGIJNEGO. PARALELIZM POMIĘZZY TRWALOŚCIA TRADYCJI ANTYCZNEJ W ŚREDNIOWIECZU, A ODRADZANIEM SIE ŚREDNIOWIECZA W INDUSTRIALNEJ KULTURZE XVIII I XIX WIEKU
}

Rola instytucji muzealnych w kreowaniu nurtów naukowych w obrębie humanistyki XIX w., a zwłaszcza w powstawaniu nowej sztuki, określona została już wielokrotnie w badaniach naukowych. Bogata literatura rozpoznała rozległe w historii formy gromadzenia przedmiotów kosztownych, sposoby przechowywania oraz ich funkcję. Muzea jako instytucje już w swojej genezie sięgają kondycji człowieka do gromadzenia, zbierania, poszukiwania rzeczy, przedmiotów, które dla niego samego stanowią indywidualną pasję bądź są rezultatem pogłębionej świadomości kultury narodowej lub rodzinnej. Nie można tego oddzielić od świadomości więzi z religią, nacją lub określoną grupą społeczną. Kryteria gromadzenia przedmiotów sztuki były różnorakie, ale ich podstawą był pietyzm dla ich wartości zarówno duchowych jak i materialnych.

W obrębie zwykłych dążeń, ambicji i pożądań rozciąga się owa potrzeba posiadania czegoś wyjątkowego, cennego, nie tylko z powodu jego wartości materialnej, ale ze względu na szacunek do czasów minionych zwłaszcza religii. Gromadzenie wytworów materialnych stanowiło i nadal stanowi ważne ogniwa łączące łańcuch historii. Pomaga również potwierdzić lub zanegować ważne rozstrzygnięcia i tezy naukowe. Przykładowo kopiowane rośliny w kodeksach medycznych średniowiecza gromadzono od czasów greckich a potem rzymskich w zbiorach różnych bibliotek, najczęściej klasztornych, pomagały one również i w czasach nowożytnych rekonstruować historię medycyny. Nawet we współczesnej farmakologii sięga się zapisów tudzież obrazów z odległej przeszłości. Zbiory przedmiotów religijnych i kultowych pomagają $\mathrm{w}$ opisie i rozumieniu odległej nieraz historii religijności nieistniejących już często kultów i rytuałów. Wiele dzieł sztuki jest świadectwem upadłych monarchii oraz rodów i stanowią 
dowody dla rekonstruowania dziejów historii politycznej Europy i świata. Wiele spośród wymienionych dziedzin czerpie odradzające się nieustannie dążenia do poznania i odkrywania przeszłości.

Od czasów starożytnych i średniowiecznych owa kondycja ludzka do zbierania i gromadzenia, kupowania lub handlowania przedmiotami sztuki jako dziełami kunsztu rąk oraz precyzji umysłu, łączy się nieustannie z dwiema formami poznawczymi człowieka: zmysłową i umysłową. Zapisana myśl w formie literackiej jako przekaz o Bogu (lub bogach), także o ludzkiej historii poszukiwała swojego obrazu ,imago”, który w jednej skondensowanej formie potrafił zamknąć obszerne wywody słowne. Dlatego zarówno dzieła spisane jak i zobrazowane, fascynowały w ich gromadzeniu. W historii dziejów cywilizacji różnorodnych kultur, dzieła sztuki zwłaszcza religijnej jak i sztuki umysłowej, traktowane były z tym samym pietyzmem i tym samym nieprzepartym dążeniem do ich gromadzenia i ochraniania jako przedmioty kosztowne, precjoza i zarazem świadectwa sacrum.

Jeżeli chcemy spojrzeć z dystansu historycznego na fenomen gromadzenia i tworzenia różnorakich zbiorów, musimy podjąć dyskurs z pojęciami i nazwami, które określają interesujące nas zjawisko lub wręcz całe procesy. W historii muzealnictwa i kolekcjonerstwa, dominującymi pojęciami niemal kluczami pozostałymi od czasów XIX-wiecznych badań, są określenia takie jak: kolekcjonowanie, zbieranie, gromadzenie, kupowanie, przekazywanie, dziedziczenie, poszukiwanie, niestety będą to także grabieże i zdobycze wojenne. Czynności te lub zabiegi, legły u podstawy powstawania muzeów, galerii, kolekcji lub zbiorów zamkniętych w obrębie rodziny, rodu ale i kolekcji udostępnianych wybranym grupom lub wręcz otwartych szerokiemu publikum. W naszych krótkich tutaj rozważaniach skierujemy refleksję nad zbieżnymi procesami związanymi z gromadzeniem reliktów przeszłości:

1. kultury antycznej w powstawaniu nowej kultury chrześcijańskiej

2. gromadzeniu dzieł sztuki średniowiecznej w ponownym odradzaniu się duchowym i humanistycznym cywilizacji industrialnej w 2 połowie XVIII i w XIX wieku.

U schyłku nowożytności i progu czasów współczesnych powstaje nieprzeparte dążenie, aby ponownie po okresie nowożytności odrodzić średniowiecze na wielorakich płaszczyznach: sztuki, nauki oraz kultury. Procesy niezwykle ważkie, które możemy tutaj jedynie skrótowo naświetlić, dotyczą dwu potężnych formacji kulturowych w ich fazach schyłku: starożytności pomiędzy V a VIII wiekiem oraz nowożytności. W pierwszym wypadku średniowiecze podjęło aktywną rolę ratowania kultury antycznej, w drugim wypadku, samo było ratowane. Wspólnym mianownikiem dla tych dwu fenomenów dziejowych był cel, troska o kulturę religijną i duchową człowieka. Świadomie pominąć musimy tutaj szereg przyczyn o charakterze politycznym, społecznym i ekonomicznym, które różniły już nie tylko pod względem kulturowym, ale i cywilizacyjnym przedłożone epoki. Skupimy się jedynie tylko na jednym aspekcie - funkcji gromadzenia dzieł sztuki.

Tworzenie się kultury wczesnochrześcijańskiej rozpoczęło mozolny proces gromadzenia dziedzictwa pogańskiego, które w swojej intelektualnej oraz przed- 
miotowej i materialnej formie, stanowiło podłoże nowej kultury chrześcijańskiej. W procesie tym dostrzega się nierozerwalną jedność w gromadzeniu zarówno duchowego jak i materialnego dorobku mijającej epoki starożytnej. Właśnie w tym zespolonym dziedzictwie, tkwiła siła rozwoju nowej kultury chrześcijańskiej. Dążenia, aby zachować spuściznę duchową grecko-rzymską widoczne są w sile intelektualnej Ojców Kościoła, zarówno w ich komentarzach pisanych do Biblii, jak i w szerszych dyskusjach związanych z nowym rozumieniem postaw etycznych oraz wyborami moralnymi skierowanymi do ludzi ówcześnie żyjących. Okres przełomu cywilizacyjnego, był tyleż trudny, co i niebezpieczny, powstały na styku często zwalczających się kultur: wschodniej i śródziemnomorskiej, greckiej i łacińskiej. Równocześnie trwały intensywne naśladownictwa i adaptacje, zarówno w sztukach: architekturze, plastyce, rzeźbie sarkofagowej, malarstwie sakralnym jak i w filozofii i nauce. Zjawiska kontynuacji i adaptacji w ówczesnej sztuce były oczywistym, twórczym działaniem, które dopiero w późniejszych badaniach historycznych, poddano podziałom stylistycznym. W stylu budownictwa chrześcijańskiego nie przypadkiem nazwanego później romańskim, odkryto wartość układu bazyliki, oraz systemu sklepień, które stały się podstawą wszelkiej architektury monumentalnej sakralnej i świeckiej. Antyczna sztuka budowania nie tylko przetrwała jako praxis, ale $\mathrm{i}$ jako obraz ukazywany w plastyce $\mathrm{i}$ w literaturze. Nawet jeżeli ciągłość i kontynuacja np. miniatorstwa nie jest możliwa w odtworzeniu dla tak odległej epoki, to z pomocą przychodzą kopie powstałe ciągu wieków V i VI, w których zachowały się formy budownictwa starożytnego jak to wykazują np. Zwój Jozuego, Ewangeliarz Rabuli, Wiener Genesis. Liczne są również zachowane dzieła naukowe, botaniczne, kopiowane w skryptoriach klasztornych oraz na dworze cesarskim w Konstantynopolu. Gromadzono i kopiowano w takim samym stopniu myśli - słowa jak i rzeczy - desygnaty ducha oraz materii. Stanowiły one spójny obszar kulturowy oraz intelektualny. Proces kumulacji dzieł, dokonywał się zrazu w pojedynczych zespołach zakonnych, dworskich, a następnie promieniował na coraz szersze kręgi społeczne. Szczególną rolę zajmują dwory cesarza Justyniana w Rawennie i w Konstantynopolu.

Zupełnie wyjątkowym zjawiskiem przewyższającym w swoim programie wymienione środowiska, było Vivarium Kasjodora (Cassiodorus, Flavius Magnus Aurelius 485-580). Przedsięwzięcie to, dokonane w atmosferze wojen politycznych, niepokojów, napadów oraz całkowitego rozpadu dawnych struktur kształcenia i kultury, było wyjątkowe pod względem siły znaczenia dla późniejszej historii. Kasjodor zgromadził w jednym kompleksie przestrzennym: szkołę, bibliotekę ze skryptorium, zbiory obrazów, rzeźb jak i cennych, pozłacanych odlewów $\mathrm{z}$ brązu. Powstało pierwsze centrum intelektualne, rekonstruujące $\mathrm{w}$ formie encyklopedycznej pisma starożytnych autorów, które on sam i jego rodzina zdołała ocalić od pożogi i zniszczeń wojennych, w których przyszło im żyć. Gromadzenie pism filozoficznych, botanicznych, kodeksów z tekstami literatury pięknej, bogato iluminowanej, stanowiło nierozłącznie rozumiane uprzedmiotowienie dobra, prawdy i piękna w dawnej konwencji greckiej. Zatem w czasach gdy już nie istniała aktywnie rozwijana nauka akademii, gromadzenie jej reliktów było realnym jej przedłużeniem, tworzeniem tego co nazywamy dziedzictwem starożyt- 
ności. Pojawiło się dążenie, aby dzieła sztuki służyły jako exemplum, jako wzór w tworzeniu nowych form. Pojęcie to było znanym i często stosowanym terminem w średniowieczu, choć jego sens nie był obcy starożytnym pisarzom. Wraz z dziełami pisanymi: kodeksami i zwojami, gromadzono przedmioty kosztowne wytwory złotnicze, precjoza z kości słoniowej, alabastru, szlachetne kamienie, o których znaczeniu tak rozlegle nauczał Pliniusz w swojej Historii Naturalnej. Nie pozbawione znaczenia było wyposażenie biblioteki Vivarium, w funkcjonalne meble: szafy, pulpity, stoły, krzesła, schowki służące przechowywaniu utensyliów pisarskich. Biblioteka udekorowana była mozaikami, jakie poznał Kasjodor w bibliotekach w Konstantynopolu, gdzie dłuższy czas mieszkał i pracował dla dworu cesarskiego. Trudno jest nam dzisiaj odtworzyć całe to wyposażenie i przedmioty, ponieważ wszystko uległo zniszczeniu. Jednak szereg szczegółów związanych z techniką pisania i wyposażenia skryptoriów przetrwało w wyposażeniu bibliotek klasztorach, zwłaszcza w centrach benedyktyńskich w Galii i Italii. Licznie zachowane obrazy piszących ewangelistów i teologów stanowią źródło wiedzy o wyposażeniu bibliotek i skryptoriów ${ }^{1}$.

Założenie i praca w Vivarium miały ogromne znaczenie dla rzeczywistej kontynuacji nauki antycznej, która właśnie dzięki temu gromadzeniu pozornie czasem rzeczy i tekstów przypadkowych, (co jest naturą gromadzenia, a nie świadomej programowej wytwórczości), stworzyła nowy rodzaj spójności wiedzy z zakresu różnych nauk i sztuk: przyrody, filozofii, literatury, kartografii, literatury pięknej, podróżniczej i dziejopisarskiej. Taki program znany był w szkole platońskiej w gaju Akademosa. Po powrocie z Konstantynopola, około roku 550, podjął swoje jedyne w tamtym czasie przedsięwzięcie, rozłożone na terenie swojej posiadłości w południowej Italii, w pobliżu Scyllacium nad morzem, ku któremu na łagodnym zboczu skłaniały się ogrody². Całość układu przestrzennego biblioteki i skryptorium dla kopistów i tłumaczy, zaplanowana była w obrębie dziedzińców stanowiących wewnętrzne ogrody z fontannami. Takie rozplanowania przestrzenne znalazło swoją kontynuację w kompozycji dziedzińców klasztornych oraz w układach szkół, które odrodziły się dopiero w nowożytnych systemach powstałych pod patronatem wielkich dworów w XV w. Znane były przykładowo na dworach: Sforzów w Mediolanie, Padwie, Ercole d Este w Ferrarze czy w prestiżowej szkole pod Mantuą znanej jako Scuola giocosa, założonej przez księcia Ludwika Gonzagę ${ }^{3}$.

Gromadzenie starożytności w początkach nowej formacji chrześcijańskiej, oznaczało zatem konserwowanie tradycji architektoniczno-przestrzennej w tak

${ }^{1}$ Licznie zachowane reliefy ukazują skrótowo jedynie zaznaczony repertuar pracowni pisarza oraz jej wyposażenia por. Age of Spirituality. Late Antique and Early Christian Art. Third to Seventh Century, red. K. Weitzmann, New York, 1978; U. Mazurczak, Inspiracja w średniowiecznych wizerunkach ewangelistów, Lublin 1990.

${ }^{2}$ M. L o h r, Kasjodora klasztor Vivarium, „Studia warmińskie”, 2 (1965) s. 375.

${ }^{3}$ G. M ü11 e r, Mensch und Bildung im italienischen Renaissance-Humanismus. Vittorino da Feltre und die humanistischen Erziehungsdenker, Baden-Baden 1984. 
zasadniczych planach, jak szkoła, biblioteka i pracownie. Ośrodek Kasjodora jednak nie tylko naśladował dawne idee, był założeniem w dużym stopniu nowym. W całym kompleksie znalazły się cele dla mnichów, które stanowiły pierwszą zrealizowaną ideę życia wspólnotowego, znaną w skupiskach monastycznych afrykańskich lub galijskich, pozbawionych jednak nobilitującego zaplecza jakie stanowiły zbiory Kasjodora. Życie wspólne łączyła modlitwa i praca fizyczna oraz kształcenie się, co razem stanowiło wzór chrześcijańskiego życia. Ów krzewiciel nowej formacji religijno-kulturowej, przywiązywał wielką wagę do indywidualnych studiów nad pogłębianiem wiedzy religijnej przez mnichów, zaś od tych, którzy nauczali, wymagał gruntownych studiów literatury i filozofii antycznej. Vivarium odsłoniło przemyślane, kompleksowe działanie, w obrębie jedności wytworów: umysłu i rąk, co jest wynikiem rozumienia idei dzieła jako wytworu umysłu oraz jego materialnego przetworzenia w celu nadania adekwatnej do idei - formy.

Dążenia Kasjodora przemyślane były w trosce o różne formy aktywności człowieka: umysłowe, artystyczne i fizyczne, które miały służyć jednemu bardzo ściśle określonemu celowi - budowaniu nowej , chrześcijańskiej paideii” wyrastającej zarówno z dziedzictwa antycznego jak intelektualnego starożytności. $\mathrm{W}$ ten sposób powstawały podstawy zarówno religijno-kulturowe jak i cywilizacyjne dla przyszłych pokoleń.

Rola Kasjodora jest nie do przecenienia właśnie wtedy, gdy wycofał się z życia politycznego, co nastąpiło w latach 538-540, gdy wojska bizantyńskie zajęły Rawennę. Pozostawiając działanie publiczne, podjął wysiłek tworzenia kultury europejskiej, co jest znamienne gdyż zniszczone były już szkoły, biblioteki i wiele innych ośrodków starożytnego Rzymu. Osłabiona została znacznie prężność nauki, chociażby w zapomnianym już języku greckim, zaś niepewna wręcz niebezpieczna sytuacja polityczna chwiała stabilnością kraju. W owym czasie pozostały już pisma uwięzionego i straconego Boecjusza (Anicius Manlius 480-524) O pocieszeniu filozofii, gdy Kasjodor realizował tę radość gromadzenia dorobku starożytnych, zarówno ich wiedzę, jak i materialną spuściznę sztuki. Odrodzenie i zachowanie życia religijnego chciał umocnić przez zorganizowanie szkoły teologicznej w Rzymie planowanej pierwotnie, o czym przekazują zachowane świadectwa rozmów Kasjodora z papieżem Agapetem (535-536) dotyczące organizacji i wyposażenia biblioteki papieskiej oraz skryptoriów, w zespole pałacowym na Lateranie ${ }^{4}$. Pochodzenie senatorskie, oraz arystokratyczne wykształcenie Kasjodora dały mu podstawy gruntownej wiedzy z zakresu kultury duchowej, ale również i bazę materialną, aby stworzyć tego rodzaju szkołę. Zbieranie, kupowanie i tworzenie kolekcji, przyczyniło się do powiększania istniejących już zasobów zebranych przez jego ród na południu Italii ${ }^{5}$.

Kasjodor Rzymianin, był już chrześcijaninem wychowanym w nowym duchu Ewangelii, pogłębionej wiedzy o całym Piśmie Świętym. Znajomość lite-

\footnotetext{
${ }^{4}$ L o h r, Kasjodora klasztor, s. 367.

${ }^{5}$ DHGE, t. 11, 1949. kol. 1349-1408.
} 
ratury rzymskiej pomogła mu w inicjowaniu i organizacji zespołów uczonych mnichów piszących komentarze do ksiąg Starego Testamentu: szczególnie Księgi Rut, Mądrości, Estery, Judyty i Ksiąg Machabejskich. Niestety całe dziedzictwo jakie stworzył Kasjodor, zarówno biblioteka rzymska jak i Vivarium nie zostały zachowane. Zniszczone i splądrowane przez plemiona germańskie a później Normanów, w znikomej części zostało uratowane przez mnichów. Przypuszcza się że część zbiorów trafiła do biblioteki klasztornej w Bobbio, gdzie przechowywane są kodeksy i różne cenne przedmioty kultu religijnego np. ampułki na oliwę z lamp palących się wokół Grobu Chrystusa. Część zbiorów natomiast znalazła się w klasztorze benedyktyńskim na Monte Cassino np. Corpus medicum Cassiodori, inne zwrócone zostały bibliotece lateraneńskiej ${ }^{6}$. Dzieło konserwowania tradycji starożytnej określa również innego wielkiego znawcę i propagatora dziedzictwa starożytnych dla tworzenia zrębu kultury chrześcijańskiej, jest nim biskup Ambroży w Mediolanie. Gromadzenie dzieł sztuki, przepisywanie kodeksów, ich oprawa jak i liczne prace translatorskie, określały cały ówcześnie zachowany system kształcenia, przejęty według wypróbowanej metody nauczania wzorowanej na sprawdzonym systemie siedmiu sztuk wyzwolonych. Dzięki takim osobowościom, jakim był biskup Ambroży, powstawały centra religijne w całej Lombardii ${ }^{7}$. Były to wspólne dążenia z papieżem, aby tworzyć nowy system kształcenia elit, tak ważnych w czasach, gdy w IX i X wieku tworzyły się wspólnoty etniczne w Europie jako zaczyn państwowości.

Chcąc sięgnąc do głębszych warstw rozumienia owego zjawiska gromadzenia dziedzictwa przeszłości, musimy wskazać na źródło owych działań, a przede wszystkim na cel. Język współczesny rozwinął cały szereg pojęć związanych z tymi działaniami, które nazywamy: zbieraniem, kolekcjonowaniem, gromadzeniem, wreszcie kupowaniem i handlowaniem. Dla czasów wczesnego średniowiecza, gdy powstawała kultura chrześcijańska, językiem podstawowym była Biblia. Z tego zakresu pochodzi także słowo wypisane na mozaice ukazującej Chrystusa tronującego w absydzie kościoła Santa Pudencjana w Rzymie. Na kartach otwartej księgi, którą trzyma Chrystus, bez trudu odczytać można inskrypcję: Christus Conservator Ecclesiae Pudenziane. Stworzona została o całe stulecie przed Kasjodorem, acz również w domu i z inicjatywy senatora, arystokraty i chrześcijanina - Pudensa ${ }^{8}$. Wyjątkowość tej inskrypcji określa także sam obraz Chrystusa tronującego, który w analogicznych kompozycjach ówcześnie tworzonych na terenach bizantyńskich lub łacińskich, określony jest słowami Ewangelii, najczęściej według św. Jana „Chrystus Logos”. Tutaj natomiast jest jedyne spośród znanych i zachowanych przedstawień Chrystusa ze słowem Conservator. Inskrypcja pochodzi z łacińskiego zakresu pojęć mających swoje odniesienie

${ }^{6}$ L o h r, Kasjodora klasztor, s. 387.

${ }^{7}$ Wszechstronną działalność biskupa Mediolanu św. Ambrożego omawiano w licznych studiach podczas konferencji organizowanej przez ks. prof. S. Longosza; materiały opublikowane są w „Vox Patrum”, 18 (1998).

${ }^{8}$ B. Brenk, Spatantike und fruhes Christentum. Propylaen Kunstgeschichte, Berlin 1985, passim. 
w Biblii. Conservator znaczy znawca, obrońca, wybawca, co zostało również odniesione do rodzaju żeńskiego conservatrix - wybawicielka. W znaczeniu eklezjalnych odniesiono ten termin do Kościoła, jako najwyższego autorytetu, także i do postaci Maryi.

W Starym Testamencie słowo to oznaczało zarządcę, urzędnika, dostawcę pokarmu, jak również opiekuna zwojów prawa. W księdze Królewskiej (1 Król $8,1-5)$ Obadiasz zaopiekował się 100 prorokami ukrywając ich w grotach w dwóch grupach po 50 osób. Podtrzymywał także ich życie, karmiąc chlebem i wodą. W księdze Izajasza (Iz. 36,3-4; 37,1-2.) występuje zarządca i pisarz których znaczenie określa także funkcja sprawowanej opieki i odpowiedzialności za słowo pisane. Zatem „conserwować” znaczy troszczyć się, a słowo to określało troskę samego Jahwe o człowieka, co przekazują Psalmy (Ps. 13,3), także o jego pracę (Syr 38, 29). Troszczyć się można zarówno o pracę człowieka jak i o wytwory tejże i jej rezultaty np. gdy jest mowa o pracy garncarza zatroskanego o swoje dzieło albo troska właściciela o wybudowany dom (Ps. 127, 1). Mieszkańcy miasta troszczą się o swoje miasto. Conserwator to ten, który opiekuje się, podtrzymuje człowieka i jego dzieła jak to czyni Bóg (Ps. 55, 23) zarówno w warstwie duchowej jak i w warstwie materialnej. W Ewangelii św. Łukasza (Łk 12,42) słowo conserwator użyte zostało w przypowieści o słudze wiernym i roztropnym, którego pan ustanowił zarządcą i wywyższył ponad służbę. Conserwator był więc opiekunem i zarazem zarządcą dóbr.

Spójrzmy zatem na działania Kasjodora i wielu innych autorytetów owych czasów, jako świadomych swojej roli arystokratów, którzy przejmując dziedzictwo własnej rodziny lub rodu, są jego zarządcami. Conserwator to nie tylko jednorazowy fakt, ale postawa i moralny etos, który określa chrześcijanina odpowiedzialnego za całe dziedzictwo pozostawione i rozpoznane w Piśmie Świętym zarówno Starego jak i Nowego Testamentu. Jest to odpowiedzialność za dziedzictwo apostolskie. Kasjodor, jak wielu innych, którzy w czasach określanych jako ciemne albo pośrednie (medii aevii), byli nie tylko zbieraczami gromadzącymi dobra, kosztowności i miracula ale byli conserwatorami, czyli opiekunami i zarządcami których celem nie było posiadanie ale troska o powierzone im dziedzictwo duchowe i materialne.

Conserwator ma swój odpowiednik w ewangelicznym pasterzu, który troszczy się o swoje owce. Dobry Pasterz to Chrystus według przekazanych słów w Ewangelii św. Jana. Określenia Pasterz i Conserwator, to określenia bezpośrednio związane z osobą Chrystusa jako wzorem do naśladowania dla każdego, który podejmuje opiekę i zarząd nad czymś, ze względu na kogoś.

Takie osobowe rozumienie spuścizny antycznej zakodowane było już w systemie kształcenia według starożytnego artes liberales, które traktował Kasjodor w sposób odnowiony. Wyraźnie odszedł od rozumienia artes liberales jako sztuki wolne, które w starożytności przeciwstawiano sztukom artes serviles. Kasjodor wprowadził systemu nauk rozumianych jako ludzkich i boskich co znalazło nowy podział: artes dla nauk praktycznych zaś discipline dla nauk teoretycznych. Bliski był ów podział z greckim rozumieniem: technaii i epistemai. W tym sensie sztuka i nauka znalazły swoją symetrię ale nie przepaść. Kasjodor utrzymał sprawdzony 
podział przedmiotów studiów: gramatykę, retorykę, dialektykę, arytmetykę, muzykę, geometrię i astronomię wskazując, że wszystkie nauki mają swoje źródło w Piśmie Świętym. Dlatego też wskazując na autorytety antycznych autorów, interpretował jednocześnie ich nauki w duchu nauki chrześcijańskiej.

Dążenie do gromadzenia dzieł antycznych, a następnie ich adaptacja do nowych kompozycji, nabrało w sztuce i kulturze karolińskiej wręcz racji w poszukiwaniu wzorca i autorytetu w przeszłości. Karol Wielki sprowadzał szereg dzieł z Rzymu lub Konstantynopola, do swojej siedziby w Akwizgranie. Nie ograniczał się do drobnych przedmiotów np. gemm antycznych, wyrobów z kości słoniowej lub złotnictwa, sprowadzał całe monumenty jak np. posąg cesarza Marka Aureliusza, który stanął przed pałacem cesarskim lub marmurowe kolumny z zespołów pogańskich świątyń, aby wkomponować je do nowych świątyń chrześcijańskich. W tym naśladowaniu antyku nie chodziło o jego przewyższenie. Studiowano jego formę, technikę wykonania, zwłaszcza w dziedzinach tak trudnych jak architektura, rzeźba, relief w marmurze lub kości słoniowej. Odlewy z brązu, miniatorstwo stały się domeną pracy twórczej w każdym klasztorze i każdym skryptorium. Plan opactwa St. Gall przygotowany na zlecenie cesarza, w r. 830 za czasów opata Gozberta, wykonany na pięciu kawałkach pergaminu wyrysowany czerwonym atramentem, przewidywał w układzie urbanistycznym miejsce na skryptorium, bibliotekę, skarbiec oraz szkołę. Wszystko razem stanowiło jeden kompleks budynków, który zapewniać miał przechowywanie - konserwowanie dzieł dawnych starożytnych, tworzenie nowych kosztowności potrzebnych w liturgii oraz kształcenie młodzieży ${ }^{9}$. Układ kościoła z jego rozbudowanymi częściami: chóru wschodniego i fasady zachodniej, był jednak nowym dążeniem do abrewiacji Trójcy Świętej, którą w analogicznych układach przestrzennych realizowały kościoły w m.in. w Reichenau, Eichstatt czy Neustadt am Main ${ }^{10}$.

Gromadzone przedmioty starożytne nie były tylko dowodem i potwierdzeniem ambicjonalnym władców karolińskich którzy czuli się spadkobiercami Rzymu cesarskiego choć ten aspekt był zapewne istotny w kształtowaniu się wielu monumentów architektonicznych. Pojawiła się potrzeba utrwalania wizerunków władców, które jako portrety włączane do kodeksów liturgicznych lub wręcz ksiąg świętych - Ewangeliarzy lub Biblii, otrzymywały sakralny sens. Ewangeliarz z Prum, prezentuje na swojej stronie incipitowej Ewangelii św. Mateusza, cztery odmalowane medaliony antyczne, które stanowią jedność z całym inicjałem Liber Generationis. Złączenie zatem z genezą Chrystusa władców świeckich stało się zrozumiałym aktem jedności rozumienia dziejów ludzkich reprezentowanych

${ }^{9}$ W. B o e c k e $1 \mathrm{~m}$ a n n, Die Wurzel der St. Galler Plankirche. Zeitschrift für Kunstgeschichte 1956, s. 24-46.

${ }^{10}$ Tamże. 
w osobach władców jako pomazańców Bożych. W dwóch górnych medalionach umieszczonych w narożnikach prawej i lewej stronie karty, ukazani zostali w profilu: Karol Wielki i jego syn Karol Łysy. W narożnikach dolnych karty odmalowane zostały natomiast monety z wizerunkami władców Rzymu oraz Izraela opisani inskrypcjami: Dawid Imperator Augustus oraz Dawid Rex Imperator. Uznanie ciągłości dziejów monarchii karolińskiej z czasem Starego Testamentu w osobie króla Dawida, legło u podstaw portretowania Karola Wielkiego jako Dawida np. tańczącego Dawida w Ewangeliarzu Koronacyjnym ${ }^{11}$. Obraz stawał się interpretacją, a widzenie zmysłowe, refleksją i namysłem intelektualnym. Takie rozumienie starożytności potwierdzała ówczesna historiozofia, którą tworzył na dworze Karola Alkuin. Właśnie ten pisarz i minister szkolnictwa określił swojego władcę jako króla Dawida: ,jest oświecony blaskiem całej mądrości, najdroższym królem Dawidem"12.

Trwanie i aktualność idei monarchii dawidowej w ciągłości Kościoła ukazuje dyptyk z kości słoniowej z Monza z IX w. Na awersie król Dawid siedzi w stroju konsula rzymskiego wzorowany na dyptykach rzymskich z V w. Na rewersie natomiast, prezentowana jest postać papieża Grzegorza Wielkiego. Karolińska idea ciągłości władzy znajdująca swoje korzenie w czasach wielkich królów starotestamentalnych, obejmowała również czasy cesarstwa rzymskiego i wielkich jego władców, do których należeli cesarz August, Julia córka cesarza Tytusa, utrwalona w wizerunkach na medalach oraz drogocennych kamieniach. Właśnie te wizerunki zbierano skrzętnie do skarbca cesarskiego. Karol Wielki posługiwał się sygnetem, w którym wtopiona była rzymska gemma $\mathrm{z}$ wygrawerowaną głową Jupitera ${ }^{13}$.

Zbieranie dzieł starożytnych utrzymali znani opaci, mecenasi sztuki, dla których idea gromadzenia dzieł antycznych była rozumiana jako konserwowanie, opieka i podtrzymywanie wzorców. Do najwybitniejszych w historii Europy należeli: biskup Ebbo z Reims, Barnward z Hildesheim, Ethelwoldt w Winchester, opat Odo z Cluny, opat Sugeriusz w St. Denis oraz opat Wibald ze Stavelot-Malmedy (1130-1158 $)^{14}$.Wybrane rzecz jasna najważniejsze postaci, spośród wielu innych w kręgu kultury klasztornej, mogą stanowić symbole kształtowania się trzech etapów kultury europejskiej zwanych pre-renesansem: karolińskiej, ottońskiej, oraz kultury uniwersyteckiej XII i początku XIII w. Wzorce i wartości, których dostarczały przedmioty oraz wiedza przekazana z czasów antycznych, kształtowały

${ }^{11}$ Karol Wielki jako Dawid zob. A. Gi e y s ztor, Władza Karola Wielkiego $w$ opinii wspótczesnej. Travaux Historiques de la Societe des Sciences et des Lettres de Varsovie, „Rozprawy Historyczne Towarzystwa Naukowego Warszawskiego" 21 (1938) z. 2, s.5-54; Prochno, Dawid Rex et Profeta, Berlin 1978.

${ }^{12}$ G. H a n d r e s o n, Wczesne Średniowiecze, Warszawa 1984, s. 112-113.

${ }^{13}$ Tamże.

${ }^{14}$ K. J. C o nant, Les eglises et la maison du chef $d$ ordre, Cambridge 1968. t. 1 passim. Exposition Wibald abbe de Stavelot-Malmedy et de Corvey (1130-1158) Catalogue, red. J. Stiennon, J. Deckers, Stavelot 1982. 
modele niezmiennego w swoim pojęciu zjawiska tradycji, którą się konserwuje i strzeże.

Wartością, którą owe przedmioty wnosiły było kształtowanie więzi, poczucia współistnienia i współtrwania z przeszłością. Mentalność tamtych ludzi rozumiała czas teraźniejszy jako współistniejący z przeszłością, zaś czas przyszły należał do Boga. Czasy przeszłe, dokonane były jednocześnie rozumiane jako aktualnie się dopełniające w teraźniejszości. Owo zakorzenienie teraźniejszości w przeszłości, było dla działania ówczesnego człowieka, zarówno na płaszczyźnie religijnej jak i naukowej, wzorcem zachowań i czynu, tworów intelektu i rąk.

W tym nurcie rozumienia przeszłości odnajdujemy sens gromadzenia kosztownych przedmiotów sztuki. Czy były one jednak rozumiane jako dzieła sztuki czy raczej jako świadectwa czasu życia i działania minionych pokoleń, które były wzorcem w podtrzymywaniu wartości? Znamienne jest, iż pośród różnych przedmiotów najbardziej cenione były portrety, wizerunki, popiersia, a nawet całe statui, których nawet często nie utożsamiano z konkretnymi osobami.

Zebrane w obszernym studium, wieloletnie badania Hermana Mc Leana dotyczące funkcjonowania portretów rzymskich w sztuce średniowiecznej, ich nieustanne odradzanie się w dziełach złotniczych w XII i XIII w. potwierdzają jak ogromne znaczenie miała „starożytna twarz" w modelach nowej sztuki religijnej ${ }^{15}$. Podnoszony już wielokrotnie w literaturze warsztat złotnika, rzeźbiarza i rysownika, Mikołaja z Verdun, potwierdza znaczenie zbiorów antycznych przedmiotów w warsztatach złotniczych np. Reims dla tworzenia nowej formy określanej mianem proto-renesansu XIII w. w rzeźbie ${ }^{16}$. Stanowią ważne ogniwo w kształtowaniu się sztuki zmysłowej, odtwarzającej człowieka w jego uwarunkowaniach cielesnych i w otoczeniu ziemskiej realnej rzeczywistości.

Postaci te jako wzorcze modele, konstruowały nie tylko adekwatne pełne wyrazu ekspresji twarze, ale stawały się exemplum dla studiów w ramach dyscyplin szkolnych jak np. retoryki. Nauka i sztuka szły nadal nierozerwalnie w parze. Retoryczna postawa, przedstawianych postaci antycznych, gesty oraz inne środki wyrazu ekspresji psychicznej manifestowanej w mimice, to wszystko przekazywały podręczniki i traktaty znane $\mathrm{w}$ antyku. Według nich komponowany był ideał postaci: poety, mówcy, filozofa, sofisty, pisarza. Opis tych kategorii i ich obrazowanie, pozostawiły od czasów późno-antycznych trwałe wzorce odrodzone w systemach dyscyplin uniwersyteckich w XIII w. Wzór obrazowy dla opisanych typów był tym, co zachowało swoją aktualność relacji pomiędzy wzorem obrazowym a podobieństwem dla konkretnej osoby.

${ }^{15} \mathrm{R} . \mathrm{H}$ a m a n n-M a c L e a n, Antikenstudium in der Kunst des Mittelalters, „Stilwandel und Personlichkeit. Gesammelte Aufsatze", Stuttgart 1988, s. 157-241.

${ }^{16}$ S. Vitali, Sicut Explorator et Spoliorum Cupidus: Zu Methode und Funktion der Antikenrezeption bei Nikolaus von Verdun, „Wiener Jahrbuch für Kunstgeschichte”, 52 (2002) s. 9-173. 
Odradzające się zainteresowanie czasami i dorobkiem średniowiecza w czasach nowożytnych daje się zauważyć w różnych etapach historii i kultury nowożytnej od połowy XVI w. Jednak wieki XVII i 1 poł. XVIII włączyły średniowieczną spuściznę kultury i sztuki, do programu mającego na celu odrodzenie duchowe i powrót do korzeni narodowych. Tendencje te wyraźne są we Francji, Niemczech także Italii, Holandii ale również i w Polsce. Jednak dopiero po rewolucji francuskiej, zniszczeniach jakich dokonano na organizmie historii, dorobku i dziedzictwie narodowym, powstał zorganizowany kierunek działań na polu naukowym. Rozwinięto badania historii Francji oraz nowoczesnej jak na owe czasy, konserwacji zabytków zarówno monumentalnych jak i plastyki. Średniowiecze stało się synonimem wspaniałości monarchii, rozwoju naukowego i splendoru sztuki francuskiej zwłaszcza w budownictwie gotyckim oraz witrażownictwie. Odkrywanie i gromadzenie dorobku średniowiecznej kultury uczyniono postawą w odrodzeniu duchowym społeczeństwa post-rewolucyjnego i w dużym stopniu zindustrializowanego. $\mathrm{Z}$ pomocą przyszły nowoczesne metody badań historycznych, językoznawstwa języków starożytnych oraz rodzimego języka francuskiego. Wysoki poziom inżynierii oraz opanowanie nowych materiałów budowlanych np. stali i żelaza, pozwoliło na nowoczesne rekonstrukcje i konserwacje zniszczonych obiektów, w czym niepodważalnym autorytetem był ówczesny inżynier, konserwator i architekt Violet le Duc (1814-1879) autor traktatu Dictionnaire raisonne de l architecture francaise du XI e au XVI e siecle (1854-1868) ${ }^{17}$.

Pragnę zwrócić uwagę na ten niezwykły paralelizm między upadkiem kultury antycznej i powstawaniem z jej elementów młodej kultury na gruncie religii chrześcijańskiej, a upadkiem kultury feudalnej i powstawaniem cywilizacji industrialnej w 2 poł. XVIII i XIX w. Spoiwem była tradycja zarówno starożytna jak i chrześcijańska w jej narodowych odłamach. Troska o przywrócenie właściwej wiedzy oraz etosu dorobku średniowiecznej Francji nie zostało wyeliminowane z oświeceniowych dążeń ogarniających całą Europę. Przyczyn było wiele i nie miejsce tutaj, aby rozwijać historię mediewistyki. Faktem jest, że można zauważyć analogiczne procesy do tamtych, odległych czasów, które przejmowały dziedzictwo antyku. Było ono wartością samą w sobie w swojej myśli filozoficznej, naukowej oraz w sztuce. Odkrywanie antyku w nowożytności, zwłaszcza w XVIII i XIX w., odbywało się na gruncie odmiennych podstaw metodologicznych, z wykorzystaniem dojrzałego aparatu naukowego językoznawstwa, historii archeologii, religioznawstwa i wielu innych dyscyplin uniwersyteckich do których należała młoda dyscyplina historii sztuki.

Fascynacja średniowieczem w omawianej epoce, wynikała między innymi z odkrycia wartości owego niegdysiejszego stopienia i asymilacji starożytności z chrześcijaństwem. Starożytności wielo-kulturowej, bo taką była hellenistycz-

${ }^{17}$ Violet le Duc krytykowany w swojej pracy, jednak bezsprzecznie jest ona istotna w konserwacji zabytków architektury gotyckiej Francji. 
na „koine”, z chrześcijaństwem również wielokulturowym, otwartym jeszcze na kultury grecko-rzymską czy syro-palestyńską. To wszystko zawierała w sobie sztuka, która teraz u progu nowoczesności gromadzono w muzeach. Impulsem do badania kultury średniowiecznej była historia nacji narodu państwa, która powstawała w obrębie średniowiecznej Europy. Powstawało wtedy wiele zbiorów i galerii sztuki średniowiecznej przy klasztorach, uniwersytetach czy też prywatnych włościach. Potwierdza to potrzebę na kulturę średniowieczną nie tylko ze względu na jej wartość rynkową, jako oddalonej epoki, może nieraz traktowanej jako fantastyki. Była ona podstawą dla tworzącej się nowej humanistyki, rozumianej jako uniwersytecka dyscyplina badawcza. Stanowiła jednocześnie wzorzec trwałych wartości duchowych dla społeczeństwa industrialnego. Łączenie teorii i wiedzy z praktyką stało się normą w działaniu, czego przykładem są takie osobowości jak Georges Seroux d Agincourt: archeolog i historyk czy wspomniany już Emmanuel Viollet le Duc którego badania ujęte zostały dziele mającym do dzisiaj niepodważalne znaczenie ${ }^{18}$.

Prace historyczne traktowały dzieła sztuki średniowiecznej jako dokument i źródło na równi z tekstem pisanym, co przypomina nam postawę Kasjodora. Mimo, że zmieniły się metody badań w naukach historycznych, czego przykładem są monumentalne publikacje Guillaume a Prospera de Barante, Histoire des ducs de Bourgogne czy prace Guillame Guizot, Jules Michelet a to ranga spójności tekstu i obrazu pozostała ta sama.

Powstanie w Paryżu Muzeum Cluny wiąże się z nurtem porewolucyjnym we Francji, której cenzusem było zburzenie Bastylii (20 lipca 1789 r.). W znanym periodyku Minerve Francais w r. 1818 napisano, że „właściwą cechą literatury romantycznej (w tym także sztuki historycznej) jest wyrażenie idei i uczuć nowego rządu zrodzonego z nowych układów społecznych". Jednak nie tylko nurty romantyczne przyczyniły się do wzrostu zainteresowań dziełami sztuki średniowiecznej. Była nią konieczność ratowania zniszczonych zabytków, podjęta przez światłych intelektualistów, do których należał Aleksander Lenoir. Powstawały pierwsze komitety organizowane społecznie, stanowiące zaczyn naukowych jednostek badawczych. Ten okres zaowocował zorganizowaniem szeregu instytucji mających już cechy organizacji muzealnej jak: Musee des Antiquites et Monuments Francais, Comite des Arts et des Monuments oraz Commision des Monuments Historiques. Posługiwano się rozwiniętym jak na owe czasy, systemem komunikacji prasowej, która publikowała akty wandalizmu, jak np. Revue des Deux Mondes. Osobowość Alexandre Lenoira, (ur. 26 grudnia 1761, zm. 11 czerwca 1839 r.) twórcy muzeum Cluny kształtowała się w domu rodzinnym, znanych w Paryżu artystów, archeologów i literatów, wraz z rodziną przeżył rewolucję i zniszczenia Notre Dame, Saint Denis oraz wielu katedr obszaru Ille de France. Młody Lenoir włączył się do akcji zbierania dzieł sztuki i organizowania magazynów, ich składu zwłaszcza zabytków zniszczonych, wymagających konserwacji. Szczególną troską otaczano dzieła wyrzucone z kościołów i klasztorów, które on sam i jego współpracownicy otaczali kultem. Zdewastowane były niemal doszczętnie

${ }^{18}$ The Dictionary of Art, 32 (1996) s. 594-599. 
w czasach jakobinów: konwent i kościół Petits Augustin, opactwo benedyktyńskie St. Denis, klasztor dominikanów i kościół St. Jaques. Gromadzenie zniszczonych dzieł zmuszało niejako do równoczesnego rozwijania prac konserwatorskich. Doprowadziły one do rychłego udostępniania publiczności narodowych depozytów np. dzieła zebrane z Petits Augustins przekazane zostały publiczności już w roku 1796 jako Musee des Antiquites et Monuments Francais stanowiąc filię Muzeum Narodowego Luwru ${ }^{19}$.

Organizacja tej ekspozycji była niezwykle nowoczesna, ponieważ twórca wykorzystał znawstwo Winckelmanna w organizacji i porządkowaniu dzieł zawarte w jego książce Geschichte des Kunst des Altertums. Sztuka uporządkowana została według jej działów i dziedzin ukazując rozwój kultury i sztuki francuskiej. $\mathrm{Z}$ tego dorobku historycznego wydzielona została ówczesna sztuka, czyli dzieła XVIII w. Nadzwyczajna wrażliwość Lenoira łączone ze znawstwem sztuki i natury, objawiały się w zorganizowaniu małego elizjum - ogrodu, którego cisza i urok miały służyć kontemplacji sztuki. Jak się okaże, bliski był założeniom naukowym nowoczesnej humanistyki, która poszukiwała jedności i komunikacji z naukami przyrodniczymi. Nastąpił proces ponownego, mozolnie odnajdywanych wzorców interdyscyplinarnej wiedzy, którą preferował już scholastyczny styl kształcenia, pogłębiony znacznie w epoce Oświecenia.

Gwałtowne przemiany polityczne, które następowały na obszarze niemal całej Europy, powodowały zmienne natężenia, akceptacje lub negacje twórcy muzeów, do których należał nawet Chateaubriand. Ostatecznie zwyciężyła grupa oponentów dążących do przekazania kościołom lub prywatnym właścicielom uratowanych przez zniszczeniami rewolucji zbiorów. Dekretem króla Ludwika XVIII wydanym 24 kwietnia 1816 r., zbiory Musee des Antiquites et des Monuments Francais miały zostać zamknięte, a dzieła oddane kościołom. Budynek mieszczący muzeum, przy którego konserwacji brał udział sam Lenoir, oddany został dla tworzącej się wówczas Ecole Royale et Speciale des Beaux - Arts.

Kontynuację dzieła Lenoira lecz już w nowej sytuacji politycznej, podjął Alexandre du Sommerard dzięki któremu powstało do dzisiaj istniejące Musee des Therme etde l Hotel de Cluny. Pałac opatów Cluny, wykupiony przez rodzinę Sommerarda oddany został dla części zbiorów, pozostała natomiast, obejmująca sztukę antyczną i wczesnochrześcijańską zorganizowana została w obrębie starożytnych rzymskich term. Muzeum od 1992 r. zostało przemianowane na Musee National du Moyen Age. Największą zasługą nowego organizatora, było uporządkowanie i szczegółowe opisanie zbiorów sztuki średniowiecznej, które znalazły naukową podbudowę w pracach Instytutu Historycznego ${ }^{20}$. Powstawanie zbiorów rozbudziło szczególne zainteresowanie sztuką i kulturą francuską czasów średniowiecznych, co znajdywało swój odpowiednik z intensywnymi badaniami ar-

${ }^{19} \mathrm{G} . \mathrm{C} \mathrm{h}$ a r $1 \mathrm{~s}$. Alexandr Lenoire and the Musee des monuments francais during the Revolution, „French historical studies” 1981, s. 200-222; M. B i a ł o n o w s k a, Musee National du Moyen Age $w$ Paryżu na tle zainteresowań kultura średniowiecza $w$ drugiej połowie XVIII $i w$ XIX wieku we Francji, Lublin 2005, mps Archiwum KUL.

${ }^{20}$ Musee National du Moyen Age. The Cluny Thermae, red. V. Huchard, Paris 2003, passim. 
chiwistów i historyków. Jednakże potrzeba zbliżenia się do tego właśnie okresu, do jego niebywałej syntezy, jaką obserwujemy w całej Europie i w Ameryce, było rezultatem nie tylko badań i zainteresowań przeszłością. W dobie porewolucyjnej i narodowowyzwoleńczej np. w Ameryce, w czasach gwałtownych przewartościowań, jakie wnosiły nowe systemy gospodarcze, ekonomiczne i kulturowe rysowała się potrzeba odnalezienia Boga i nowej drogi, aby odbudować wiarę $\mathrm{W}$ istnienie wartości ostatecznych, w czym pomóc miała sztuka podobnie jak właśnie ona budowała niegdyś nową wiarę chrześcijańską.

Dążenia te obserwuje się również w Stanach Zjednoczonych Ameryki Północnej, która nigdy nie posiadała własnych zbiorów sztuki średniowiecznej. Pojawiła się potrzeba sprowadzania za ocean całych klasztorów, które stanowiły miejsce dla zbiorów średniowiecznych, czego przykładem jest The Closters Museum w Nowym Jorku jako część Metropolitan Museum of Art, położone w północnym Manhattanie w Fort Tryon Park. Początki tworzenia tych zbiorów sięgają r. 1873, stopniowo powiększane przez wielu kolekcjonerów: J. Pierponta Morgana, Georga Blumenthala, Michaela Fridsama, Frederica Pratta oraz Irwina Untermeyera $^{21}$.

Rdzeniem Galerii Średniowiecznej jest pięć krużganków klasztornych sprowadzonych z Francji przez Greya Bernarda i Johna Rockefellera. G. Bernard, jako student Ecole des Beaux Arts zainteresował się sztuką średniowieczną zwłaszcza architekturą romańską, której relikty zbierał dzięki wsparciu finansowemu J. Rockefellera. Swoje szczególne zainteresowania skierował ku okolicom Fontainebleau kupując od tamtejszych rolników fragmenty rzeźb oraz detale architektoniczne pochodzące $\mathrm{z}$ pobliskich klasztorów. Z kawałków ścian odtworzył niewielki, ale za to jakże sugestywny układ bazyliki. Jej część portalowa pochodziła z kościoła w Reugny, okna z kościoła w Sens, zaś absyda chóru wschodniego z kościoła w Langon. Krużganki złożono z części przywiezionych z klasztorów: Saint Michel de Cuxa, Saint Guihem de Desert z Trie oraz z Froville. Nowością wystawienniczą było umożliwienie zwiedzającym bezpośredniego kontaktu z dziełem sztuki, jego prawdziwego oglądu i doświadczenia jako namiastki prawdziwego zespołu sakralnego. Odejście od oglądania „,przez szybę” było próbą zrealizowania do tej pory teoretycznego doświadczenia pierwotnego sensu dzieła sztuki jako nośnika wiary i pobożności. Znaczne powiększenie swojej powierzchni zawdzięczają zbiory Rockefellerowi, który oddał pod budowę nowych obiektów muzealnych około 60 akrów ziemi nad rzeką Hudson ${ }^{22}$.

Przytoczone tutaj epizodycznie dwa skrajne w swojej geografii przykłady organizowania sztuki średniowiecznej, nie stanowią wyjątku, wręcz potwierdzają powszechność tego zjawiska obserwowanego w wielu krajach np. w Niemczech, Anglii czy Hiszpanii. Ów sentyment dla przeszłości, który miał konkretne wspar-

${ }^{21}$ K. R. B rown, T. B. Hu s b and, T. C. T. Litt1 e, Medieval Art and the Cloisters, the Metropolitan Museum of Art, „Art Bulletin”, 47 (1989/1990) nr. 2 s. 14-19; J. R o r i m e r, Medieval Monuments at the Cloisters as they were and as they are New York 1972, w: Medieval Art in America. Patterns of Collecting 1800-1940, red. E. Bradford Smith, New York 2006.

${ }^{22}$ Tamże. 
cie finansowe, nie był jednak zwykłym koneserstwem, a jeżeli nawet to nie stanowiło ono u podłoża genezy tak szeroko zakrojonych przedsięwzięć badawczych, lecz rezultatem znacznie ważniejszych procesów. Poszukiwania nowego odrodzenia sfery duchowej i religijnej w społeczeństwach, które nabrały rozpędu nowoczesności, poszukiwały nowego rozumienia i tym samym badania humanistyki wzmocnionej naukami przyrodniczymi. Dzieła sztuki, dzieła umysłu znajdywały nowe miejsce w świadomości nie tylko uczonych badaczy, ale i zbieraczy, których działania były zbliżone tym, jakie wykształcił Kasjodor.

Nowe potrzeby humanistyki, jej badania i jej nauczania zakreślali wybitni filozofowie tej miary co Wilhelm Dilthey (1833-1911), metodolog humanistyki, teoretyk kultury, profesor w Bazylei i Berlinie ${ }^{23}$. W filozofii tego humanisty przeszłość utrwalona została w żywych więzach jednostki ze światem, czy jak to nazywał duchem obiektywnym. Poszukiwał on związków pomiędzy naukami, które łączy wartość poznawcza świata jako organizmu dynamicznego, a nie statycznego. Świat był dla W. Diltheya w nieustannym procesie budowy, który gwarantowała mu jego wewnętrzna moc duchowa. Nic lepiej nie mogło ilustrować takiej definicji kultury jak właśnie sztuka średniowieczna, która była doskonałą syntezą kultury i wiedzy o Bogu i o świecie. Sztukę rozumiano w całości i jedności dorobku artystycznego: urbanistyki, architektury, plastyki, wyrastającego ze starożytności. Tak interpretowane średniowieczne relikty sztuki chrześcijańskiej były jednocześnie pierwszym utrwalaczem dorobku kultury i religii pogańskiej. Swoją krytykę filozofii dziejów nazwał aktualizowaniem budowanym dzięki czy poprzez nauki historyczne. Historia bowiem pośród wszelkich krępujących ideologii jest osnową i miejscem prawdy. Autor jasno sformułował swój program $\mathrm{w}$ dziele Einleitung in die Geisteswissenschaften.

Odrzucenie przez badacza metafizyki jako siły kierującej światem i historią, nie oznaczało odrzucenia Boga, który jest i oddziałuje na dzieje świata ${ }^{24}$. Świat kultury starożytnej był dla Diltheya dziedziną utrwalonych ekspresji duchowych z przeszłości, a młode chrześcijaństwo uzyskało własną samowiedzę dzięki historii która je poprzedzała. Historia obejmuje zespół dokumentów pisanych jak i tworów materialnych, znajdujących swoje szczególne miejsce nie tyle w obrębie działań nabywczo-finansowych, co w dążeniu do konstytuowania i odkrywania kategorii prawdy.

Wyrazem troski o człowieka w czasach tworzenia się nowoczesnych nauk humanistycznych w XIX w., były poszukiwania źródeł religijnych narodowych, znajdujące swój wyraz również w gromadzeniu i konserwowaniu dzieł sztuki. W. Dilthey podkreślał znaczenie pietyzmu niemieckiego wpisującego się do chrześcijańskich ruchów religijnych, przenikających środowiska zarówno europejskie jak i amerykańskie. Łączyła je troska o zachowanie wiary i tradycji Kościoła. Zra-

${ }^{23}$ W. D ilth e y, Budowa świata historycznego w naukach humanistycznych, oprac. E. Paczkowska-Łagowska, Gdańsk 2004, passim.

${ }^{24}$ Tamże, s. 336. 
zu niewidoczny, stopniowo silniej rysujący się wspomniany ruch pietystów ostro przeciwstawiał się dążeniom kościoła protestanckiego, który nie gromadził dzieł sztuki religijnej, co prowadzić miało ku narodowemu zeświecczeniu, tak w formacji duchowej jak i w życiu publicznym. Ocenę jaką wystawiały ruchy chrześcijańskiego pietyzmu czy pietystów pozostawiamy teologom i historykom jednak jest dla nas faktem, iż ten właśnie ten nurt przyczynił się do ożywienia zbieractwa kolekcjonowania i kształtowania galerii średniowiecznych. On utrwalił postawę odrodzenia religijno-narodowego. W naturze doświadczenia religijnego, w czym partycypuje obraz lub innego rodzaju dzieło sztuki religijnej, tkwi pragnienie nawrócenia, poprzez wskazywanie rangi doświadczenia, jakie wnosi historia.

Ten nurt odrodzenia religijności poprzez historię i doświadczenie ducha dziejowego pojawił się znacznie wcześniej, w XVII wieku w Niderlandach. Na ten fakt wskazuje Dilthey powołując się na list Kartezjusza przesłany r. 1643 Voetiusowi udowadniając, że filozofia rozumu jest zbieżna z pietyzmem, z odrodzeniem religijnym ${ }^{25}$. Teolog bowiem na podstawie Biblii, dzieła racjonalnego i historycznego, próbuje wskazać na prawdziwy system nauki chrześcijańskiej.

W koncepcji humanistyki Diltheya znalazła się sztuka, jako dziedzina doświadczenia i rozumu, która może spełniać rolę spoiwa przeszłości z teraźniejszością, transcendencji z rzeczywistością ${ }^{26}$. Autor świadom był, że to właśnie wieki XVIII i XIX odkryły ponownie prawdę o dziele sztuki jako obszaru jedności poznania, duchowego i jedności twórczości. W traktacie o poezji Einbildungskraft des Dichters z 1887 r., domagał się Dilthey przywrócenia reguł poetyki Arystotelesa, co miało przywrócić ład w panującej anarchii. Domaganie się tego myśliciela, aby humanistyce przywrócić jej oczywisty związek z religią, znalazło swoją kontynuację w groźnych napomnieniach także innych myślicieli i krytyków sztuki do których należał Hans Sedlmayer, który określił muzeum jako symptom epoki bez Boga ${ }^{27}$, będące rezultatem utraty środka ${ }^{28}$. Refleksje tego autora należą jednak do zupełnie innej sztuki oraz krytyki. Od najwcześniejszych kolekcji, które ochraniały dzieła kultury antycznej rozumianej jako spójne dziedzictwo nauki i sztuki - rozumu i wiary, gromadzone przez średniowiecznych, dla wzmocnienia autorytetu wiary i nauki obserwujemy ten sam niezachwiany niczym proces jedności wytworów rozumu i rąk partycypujących w kulturze. Musimy jednak sobie uzmysłowić fakt, że kultura była jednością, którą stanowiły działania skierowane ku Bogu i ku człowiekowi. Tak właśnie rozumiana jedność, pomagała odrodzić wiarę religię i kulturę w okresie zawirowań XVIII i XIX w. Dlatego tak ważną rolę odegrały organizowane muzea sztuki zwłaszcza sztuki średniowiecznej. Hans

25 Tamże.

${ }^{26}$ H. S c h a d e, Zur Kunsttheorie Wilhelm Diltheys, „Probleme der Kunstwissenschaft. Kunstgeschichte und Kunsttheorie im 19 Jahrhundert", t. 1 Berlin 1963, s. 81.

${ }^{27}$ M. B r y 1, H. S e d 1 m a y r, Muzeum jako symptom ,epoki bez Boga”, w: Muzeum sztuki, red. M. Popczyk, Kraków 2005, s. 59-85.

${ }^{28}$ Verlust der Mitte, Die bildende Kunst des 19. und 20. Jahrhunderts als Symptom und Symbol der Zeit, Salzburg 1948. 
Sedlmayer obserwował i przeżywał zjawiska poddane już rozdzieleniu: wiary od kultury, nauki od sztuki, a doświadczenia od wrażeniowości ${ }^{29}$. Może jest szansa, aby dzieła sztuki religijnej otwarte dla odbiorcy partycypowały w życiu religijnym, w przeżywaniu prawd wiary, nie tylko jako chwilowy proces. Dzieła są jako exemplua ludzkości, a zbieracze powinni powróć głębszą świadomość znaczenia conservatora.

29 Tamże. 